\title{
Amitriptyline and aerobic exercise or amitriptyline alone in the treatment of chronic migraine: a randomized comparative study
}

\author{
Amitriptilina e exercício aeróbico ou amitriptilina isolada no tratamento da migrânea \\ crônica: um estudo randomizado e comparativo \\ Michelle Dias Santos Santiago, Deusvenir de Souza Carvalho, Alberto Alain Gabbai, Mariana Machado \\ Pereira Pinto, Andrea Regina Correa Moutran, Thais Rodrigues Villa
}

\begin{abstract}
To compare the preventive treatment benefits of amitriptyline and aerobic exercise or amitriptyline alone in patients with chronic migraine. Method: Sixty patients, both genders, aged between 18 and 50 years, with a diagnosis of chronic migraine, were randomized in groups called amitriptyline and aerobic exercise or amitriptyline alone. The following parameters were evaluated: headache frequency, intensity and duration of headache, days of the analgesic medication use, body mass index (BMI), Beck Depression Inventory (BDI) and Beck Anxiety Inventory (BAI) scores. Results: In the evaluated parameters, was observed decrease in headache frequency $(p=0.001)$, moderate intensity $(p=0.048)$, in headache duration ( $p=0.001)$, the body mass index ( $p=0.001)$, Beck Depression Inventory $(p=0.001)$ and Beck Anxiety Inventory scores $(p=0.001)$, when groups were compared in the end of third month. Conclusion: In this study, the amitriptyline was an effective treatment for chronic migraine, but its efficacy was increased when combined with aerobic exercise.
\end{abstract}

Keywords: chronic migraine, adults, prophylaxis, amitriptyline, aerobic exercise.

\section{RESUMO}

Comparar os benefícios do tratamento preventivo em pacientes com migrânea crônica utilizando a amitriptilina associada ao exercício aeróbico ou amitriptilina isolada. Método: Sessenta pacientes de ambos os sexos com idade entre 18 e 50 anos e com diagnóstico de migrânea crônica foram randomizados para receber amitriptilina e orientados a: praticar exercícios aeróbicos ou somente a amitriptilina isolada. Os seguintes parâmetros foram avaliados: frequência, intensidade e duração da cefaleia, dias de uso de medicação analgésica, índice de massa corporal (IMC), e pontuação nas escalas de Beck Depression Inventory (BDI) e Beck Anxiety Inventory (BAI). Resultados: Nos parâmetros avaliados, houve redução na frequência da cefaleia ( $p=0,001)$, intensidade moderada ( $p=0,048)$, na duração ( $p=0,001)$, no índice de massa corporal ( $p=0,001)$, e pontuação nas escalas Beck Depression Inventory $(p=0,001)$ e Beck Anxiety Inventory ( $p=0,001)$, quando os grupos foram comparados ao final do terceiro mês. Conclusão: A amitriptilina foi um tratamento eficaz para a migrânea crônica, mas sua eficácia foi maior quando combinada com exercício aeróbio.

Palavras-chave: migrânea crônica, adultos, profilaxia, amitriptilina, exercício aeróbio.

Chronic migraine is a disabling disease, with a negative impact on the individual's ability to perform daily activities ${ }^{1}$ affecting $2 \%$ to $3 \%$ of the general population ${ }^{2}$ and with the prevalence in Brazilian population of $5 \%^{3}$.

The quality of life in patients with chronic migraine have significant impairments compared to the healthy population and also when compared to other chronic conditions ${ }^{4}$, and $85 \%$ of these patients have disabling attacks, justifying the introduction of prophylactic treatment ${ }^{5}$.
In episodic migraines, amitriptyline has been used as prophylactic therapy in the last 45 years, and is generally accepted as an effective drug ${ }^{6}$.

In addition to reducing the frequency, duration and intensity of headache attacks, therapy with amitriptyline may improve the response to acute treatment, reduce disability, and reduce associated economic costs ${ }^{7,8}$.

The use of amitriptyline for treatment of migraine resulted in 50\% reduction in the headache frequency.

Departamento de Neurologia e Neurocirurgia, Universidade Federal de São Paulo, Sao Paulo SP, Brazil.

Correspondence: Thais Rodrigues Villa; Rua Dr. Bacelar 231, cj. 17; 04026-000 São Paulo SP, Brasil; E-mail: contato@cefaleiaweb.com.br

Conflict of interest: There is no conflict of interest to declare.

Received 17 March 2014; Received in final form 11 July 2014; Accepted 31 July 2014. 
Studies demonstrated reduction in headache intensity and frequency of amitriptyline group compared to the group venlafaxine ${ }^{9}$, reduction in the frequency and duration of headache compared to placebo ${ }^{7}$. Others studies observed similar results ${ }^{10,11}$.

A significant reduction in the use of analgesic medication was related after prophylaxis with topiramate (50-100 mg/day) associated with amitriptyline (10-20 mg/day) in migraneurs with overuse of analgesic medicines ${ }^{12}$.

The use of amitriptyline for treatment of migraine requires initial doses of 10 to $25 \mathrm{mg}$, and the effective therapeutic dose ranges from 25 to $200 \mathrm{mg}^{13}$.

Studies with amitriptyline demonstrate limited evidence that the treatment may be beneficial for patients with chronic migraine ${ }^{14}$.

Although several studies addressing prophylactic treatment for episodic migraine 6 ,7,8,9,10,11,12,13,14 , only topiramate ${ }^{15}$ and the botulinum toxin ${ }^{16}$ were effective in placebo-controlled studies for the prophylactic treatment of patients with chronic migraine.

In addition to the prophylactic drug therapies, multiple studies have shown benefits of non-pharmacological interventions such as aerobic exercise 17,18,19,20,21,22,23,24 $^{\text {Exercise of }}$ moderate intensity and practiced regularly can promotes muscle relaxation, improved cardiovascular fitness and also reduces the frequency, intensity and duration of headache $\operatorname{attacks}^{19}$.

Hypotheses for the mechanisms by which exercise may reduce headache include decreased peripheral sensitization and activation of descending inhibitory pathways ${ }^{25}$.

Studies where the exercise was supervised by a physical therapist demonstrated higher patient compliance ${ }^{18,19,20}$. However, even the studies without supervision, with exercises performed at home, positive results have been reported $^{20,21}$. Despite of positive findings, these studies showed some limitations as a lack of control groups and subjective endpoints.

The aim of this study was to compare the combination of amitriptyline and aerobic exercise with amitriptyline alone in the prophylactic treatment of patients with chronic migraine, in a randomized controlled open label trial. The following parameters were evaluated: headache frequency, intensity and duration of headache, days of the analgesic medication use, body mass index (BMI), Beck Depression Inventory (BDI) and Beck Anxiety Inventory (BAI) scores.

\section{METHOD}

Over a 2-year period (June 2010 through June 2012), patients newly admitted to the out-patient Division of Investigation and Treatment of Headaches (DITH) of the Universidade Federal de São Paulo (Unifesp), both genders, aged between 18 and 50 years, all diagnosed with chronic migraine by the criteria of "The International Classification of Headache Disorders (ICHD-II, 2004)"26, were included in the studies.

Inclusion criteria: patients diagnosed with chronic migraine, normal cardiac and neurological examination, who had not been practicing exercise for at least 3 months.

Exclusion criteria: previous use in the last year of medication with action in the central nervous system, including migraine prophylactics, other systemic, neurological and psychiatric disorders, inability to understand verbal commands and to perform aerobic exercise, not treatment compliance during the study.

In neurological evaluation, patients with medication overuse were instructed to perform a washout of all analgesic medicines and an abortive therapy with naproxen sodium $550 \mathrm{mg}$ maximum twice a week and non-pharmacological practices were oriented. In psychological evaluation, patients were instructed to fill out Beck Depression Inventory and Beck Anxiety Inventory. After neurological and psychological evaluation patients were simple randomized, using computergenerated random numbers, in two groups:

- Amitriptyline alone: patients using amitriptyline (25 mg/day);

- Amitriptyline and aerobic exercise: patients using amitriptyline (25 mg/day) combined with aerobic exercise.

In the aerobic exercise program patients were instructed to perform a 40 minutes fast walk outdoors with a frequency of 3 times/week for 12 consecutive weeks ${ }^{27}$ and daily, fill out a headache questionnaire. All patients received written instructions and performed a training session with physiotherapist.

Instruments used in the amitriptyline group and aerobic exercise: headache questionnaire, explanatory leaflet about the warm-up exercises, spreadsheet with hours of exercise performance, Borg scale ${ }^{28}$ and measurement of heart rate on the initial and final walk.

Instruments used in the amitriptyline group alone: headache questionnaire.

The following parameters were evaluated: headache frequency (days/month), headache intensity 1 (mild), 2 (moderate) and 3 (disabling), duration/day of headache (6h, 12h, 18h e 24h), analgesic medication use (days/month), body mass index, Beck Depression Inventory and Beck Anxiety Inventory at baseline and in the end of the $3^{\text {rd }}$ month. Also the patients were weekly assessed by telephone calls and informed the study authors about the evolution of proposed therapies.

The study was submitted and approved by the local Ethic Committee in Research, and all participants signed an informed consent form, but they were able to leave the study anytime and for any reason. 
Table 1. Patients in amitriptyline alone $(n=30)$ and amitriptyline and aerobic exercise group $(n=30)$ according to the average age, gender and average onset migraine.

\begin{tabular}{lccc} 
Variable & Group Amitr alone $\pm S D$ & Group Amitr and exer $\pm S D$ & $p-v a l u e$ \\
\hline Average age $(y) \pm S D$ & $35 \pm 8$ & $31 \pm 9$ & 0.170 \\
Gender $(\%)-F: M$ & $88: 12$ & $79: 21$ & 0.370 \\
Average onset of migraine $(y) \pm S D$ & $17 \pm 10$ & $13 \pm 11$ & 0.189 \\
\hline
\end{tabular}

\section{Statistical analysis}

For statistical analysis, Student's $t$-test was used. The significance level was $\mathrm{p} \leq 0.05$. The Minitab was Statistical Software utilized.

\section{RESULTS}

Sixty patients were randomized for the study, 30 in amitriptyline alone group and 30 amitriptyline and aerobic exercise group.

In amitriptyline alone group 4 withdrew from the study for not using the medication correctly or not could tolerate the medication side effects (drowsiness and dry mouth) and in amitriptyline and aerobic exercise group 6 withdrew for non-adherence to proposed physical treatment.

The comparison of mean age, gender, and onset time of migraine between the groups were shown in Table 1.
Fifty patients reached the end of study. In the evaluated parameters, was observed decrease in headache frequency $(\mathrm{p}=0.001)$, duration of headache attacks $(\mathrm{p}=0.001)$ intensity moderate $(\mathrm{p}=0.048)$, the body mass index $(\mathrm{p}=0.006)$, Beck Depression Inventory $(\mathrm{p}=0.001)$ and Beck Anxiety Inventory scores $(\mathrm{p}=0.001)$ between the groups amitriptyline alone $(\mathrm{n}=26)$ and amitriptyline and aerobic exercise group $(\mathrm{n}=24)$, as summarized on Table 2.

\section{DISCUSSION}

This study showed that the combination of a prophylactic drug therapy amitriptyline with a non-pharmacological treatment aerobic exercise was effective as a preventive therapy as compared with amitriptyline alone.

There is no consensus in the literature about how patients with chronic migraine should be instructed to

Table 2. Results of headache frequency (days/month), duration and intensity of headache attacks (attacks/month), use of analgesic medication (days/month), body mass index (BMI), Beck Depression Inventory (BDI) and Beck Anxiety Inventory (BAI) scores at baseline and the end of the 3rd month in amitriptyline alone $(n=26)$ and amitriptyline and aerobic exercise group $(n=24)$

\begin{tabular}{|c|c|c|c|c|}
\hline Variable & Evaluation & Group Amitr alone $\pm S D$ & Group Amitr and exer \pm SD & $p$-value \\
\hline \multirow[t]{2}{*}{ Frequency } & initial & $25 \pm 6.31$ & $23 \pm 6.11$ & \\
\hline & $3^{\text {rd }}$ month & $13 \pm 6.41$ & $5 \pm 2.21$ & $0.001 * *$ \\
\hline \multirow[t]{2}{*}{ Duration (6h) } & initial & $1 \pm 3.14$ & $4 \pm 9.74$ & \\
\hline & $3^{\text {rd }}$ month & $4 \pm 2.94$ & $3 \pm 1.79$ & $0.017^{\star}$ \\
\hline \multirow[t]{2}{*}{ Duration (12h) } & initial & $13 \pm 7.50$ & $3 \pm 12.1$ & \\
\hline & $3^{\text {rd }}$ month & $1 \pm 4.62$ & $6 \pm 1.74$ & $0.001 * *$ \\
\hline \multirow[t]{2}{*}{ Duration (18h) } & initial & $5 \pm 9.13$ & $2 \pm 3.26$ & \\
\hline & $3^{\text {rd }}$ month & $3 \pm 2.53$ & $1 \pm 1.02$ & 0.733 \\
\hline \multirow[t]{2}{*}{ Duration (24h) } & initial & $20 \pm 13.9$ & $20 \pm 11.0$ & \\
\hline & $3^{\text {rd }}$ month & $3 \pm 6.19$ & 0 & $0.001 * *$ \\
\hline \multirow[t]{2}{*}{ Intensity 1 (mild) } & initial & $10 \pm 8.68$ & $8 \pm 8.38$ & \\
\hline & $3^{\text {rd }}$ month & $5 \pm 3.18$ & $3 \pm 2.16$ & 0.528 \\
\hline \multirow[t]{2}{*}{ Intensity 2 (moderate) } & initial & $13 \pm 6.89$ & $14 \pm 7.57$ & \\
\hline & $3^{\text {rd }}$ month & $6 \pm 4.75$ & $3 \pm 1.86$ & $0.048^{\star}$ \\
\hline \multirow[t]{2}{*}{ Intensity 3 (disabling) } & initial & $6 \pm 5.50$ & $6 \pm 6.55$ & \\
\hline & $3^{\text {rd }}$ month & $2 \pm 2.65$ & 0 & 0.093 \\
\hline \multirow[t]{2}{*}{ Analgesic Medication } & initial & $20 \pm 9.63$ & $16 \pm 8.95$ & \\
\hline & $3^{\text {rd }}$ month & $3 \pm 2.99$ & $1 \pm 1.48$ & 0.752 \\
\hline \multirow[t]{2}{*}{$\mathrm{BMI}$} & initial & $24 \pm 2.66$ & $24 \pm 2.57$ & \\
\hline & $3^{\text {rd }}$ month & $25 \pm 2.92$ & $23 \pm 2.64$ & $0.006 * *$ \\
\hline \multirow[t]{2}{*}{ BDI } & initial & $14 \pm 11.45$ & $10 \pm 6.70$ & \\
\hline & $3^{\text {rd }}$ month & $10 \pm 11.20$ & $6 \pm 5.69$ & $0.001 * *$ \\
\hline \multirow[t]{2}{*}{ BAl } & initial & $16 \pm 15.85$ & $15 \pm 8.91$ & \\
\hline & $3^{\text {rd }}$ month & $10 \pm 12.10$ & $8 \pm 7.17$ & $0.001 * *$ \\
\hline
\end{tabular}

${ }^{\star} p$-value $=0.05 ;{ }^{*} p-$ value $=0.001$ 
perform aerobic exercise ${ }^{19}$, so the parameters of intensity, frequency and duration of exercise were based on the parameters used for the healthy population ${ }^{27}$.

The regular practice of aerobic exercise seems to benefit patients with migraine ${ }^{17,18,19,20,21,22,23,24}$. These benefits could be related to increased production of beta-endorphins ${ }^{18}$ or changes in levels of nitric oxide during aerobic exercise ${ }^{17}$. Controlled studies are needed to define the optimal frequency and intensity of exercise ${ }^{20}$.

Studies showed difference in pain intensity between groups ${ }^{19,24}$ and this study also showed a significant reduction in these evaluated groups.

Despite of findings of decreased intensity, duration and frequency of headache in physically active people, there are few studies about the real influence of exercise in patients with headache ${ }^{21}$.

Many patients with chronic migraine report that exercise exacerbates their headaches ${ }^{20}$. However, in this study was not observed worsening of headache in chronic migraine patients.
Obesity is a risk factor to migraine chronicity $^{29}$. Despite the weight gain, the amitriptyline group alone had a reduced frequency of headache attacks. The combination of amitriptyline and aerobic exercise resulted in no increase in body mass index, therefore, in addition to resulting in greater efficacy of headache prevention, exercise can also prevent the adverse effect of weight gain associated with the use of amitriptyline.

This study had some limitations such as the small samples of patients evaluated, the aerobic exercise have been done by patients without supervision. However other studies without supervision and with the exercises performed at home led to similar results ${ }^{18,19,20,21}$.

In conclusion, the therapy with amitriptyline was effective as a prophylactic treatment for patients with chronic migraine, however the combination of amitriptyline and aerobic exercise resulted in an even greater reduction in the frequency, duration and intensity of headache, in body mass index, Beck Depression Inventory and Beck Anxiety Inventory scores.

\section{References}

1. Diener H-C, Dodick DW, Goadsby PJ, Lipton RB, Olesen J, Silberstein SD. Chronic migraine: classification, characteristics and treatment. Nat Rev Neurol. 2012;8(3):162-71. http://dx.doi.org/10.1038/nrneurol. 2012.13

2. Aurora SK, Kulthia A, Barrodale PM. Mechanism of chronic migraine. Curr Pain Headache Rep. 2011;15(1):57-63. http://dx.doi.org/10.1007/ s11916-010-0165-z

3. Queiroz LP, Peres MFP, Kowacs F, Piovesan EJ, Ciciarelli MC, Souza JA et al. Chronic daily headache in Brazil: a nationwide population-based study. Cephalalgia. 2008;28(12):1264-9. http://dx.doi.org/10.1111/ j.1468-2982.2008.01670.x

4. Mercante JPP, Bernik MA, Zukerman-Guendler V, Zukerman E, Kuczynski E, Peres F. Comorbidade psiquiátrica diminui a qualidade de vida de pacientes com enxaqueca crônica. Arq Neuropsiquiatr. 2007;65(3B):880-4. http://dx.doi.org/10.1590/s0004$282 \times 2007000500031$

5. Bordini CA. Tratamento profilático. In: Speciali JG, Silva WF, editores. Cefaléias. São Paulo: Lemos; 2002. p. 90-101.

6. Silberstein SD, Goadsby PJ. Migraine: preventive treatment. Cephalalgia. 2002;22(7):491-512. http://dx.doi.org/10.1046/j.14682982.2002.00386.x

7. Modi S, Lowder DM. Medications for migraine prophylaxis. Am Fam Physician. 2006;73(1):72-8.

8. Gomersall JD, Stuart A. Amitriptyline in migraine prophylaxis. Changes in pattern of attacks during a controlled clinical trial. $J$ Neurol Neurosurg Psychiatry. 1973;36(4):684-90. http://dx.doi.org/ 10.1136/jnnp.36.4.684

9. Bulut S, Berilgen MS, Baran A, Tekatas A, Atmaca M, Mungen B. Venlafaxine versus amitriptyline in the prophylactic treatment of migraine: randomized, double-blind, crossover study. Clin Neurol Neurosurg. 2004;107(1):44-8. http://dx.doi.org/10.1016/j.clineuro. 2004.03.004

10. Smitherman TA, Walters AB, Maizels M, Penzien DB. The use of antidepressants for headache prophylaxis. CNS Neurosci Ther. 2011;17(5):462-9. http://dx.doi.org/10.1111/j.1755-5949.2010.00170.x
11. Couch JR. Amitriptyline in the prophylactic treatment of migraine and chronic daily. Headache. 2011;51(1):33-51. http://dx.doi.org/10.1111/ j.1526-4610.2010.01800.x

12. Valguarnera F, Tanganelli P. The efficacy of withdrawal therapy in subjects with chronic daily headache and medication overuse following prophylaxis with topiramate and amitriptyline. Neurol Sci. 2010;31(1 Suppl):S175-7. http://dx.doi.org/10.1007/s10072-010-0319-0

13. Silberstein SD. Preventive migraine treatment. Neurol Clin. 2009;27(2):429-43. http://dx.doi.org/10.1016/j.ncl.2008.11.007

14. Straube A, Gaul C, Förderreuther S, Kropp P, Marziniak M, Evers S et al. Therapy and care of patients with chronic migraine. Nervenarzt. 2012;83(12):1600-8. http://dx.doi.org/10.1007/s00115-012-3680-9

15. Silberstein SD, Lipton RB, Dodick DW, Freitag FG, Ramadan N, Mathew $\mathrm{N}$ et al. Efficacy and safety of topiramate for the treatment of chronic migraine: a randomized, double-blind, placebo-controlled trial. Headache. 2007;47(2):170-80. http://dx.doi.org/10.1111/j.15264610.2006.00684.x

16. Diener HC, Dodick DW, Aurora SK, Turkel C, DeGryse R, Lipton R et al. OnabotulinumtoxinA for treatment of chronic migraine: results from the double-blind, randomized, placebo-controlled phase of the PREEMPT 2 trial. Cephalalgia. 2010;30(7):804-14. http://dx.doi.org/ 10.1177/0333102410364677

17. Narin SO, Pinar L, Erbas D, Oztürk V, Idman F. The effects of exercise and exercise-related changes in blood nitric oxide level on migraine headache. Clin Rehabil. 2003;17(6):624-30. http://dx.doi.org/10.1191/ 0269215503 cr657oa

18. Köseoglu E, Akboyraz A, Soyuer A, Ersoy AO. Aerobic exercise and plasma beta endorphin levels in patients with migrainous headache without aura. Cephalalgia. 2003;23(10):972-6. http://dx.doi.org/ 10.1046/j.1468-2982.2003.00624.x

19. Donna-Marie C, Lockett MA, Campbell JF. The effects of aerobic exercise on migraine. Headache. 1992;32(1):50-4. http://dx.doi.org/ 10.1111/j.1526-4610.1992.hed3201050.x

20. Varkey E, Sider A, Carlsson J, Linde M. A study to evaluate the feasibility of an aerobic exercise program in patients with migraine. 
Headache. 2009;49(4):563-70. http://dx.doi.org/10.1111/j.1526-4610. 2008.01231.x

21. Busch $V$, Gaul C. Exercise in migraine therapy: is there any evidence for efficacy? A critical review. Headache. 2008;48(6):890-9. http://dx. doi.org/10.1111/j.1526-4610.2007.01045.x

22. Domingues RB, Teixeira AL, Domingues SA. Physical practice is associated with functional disability in medical students with migraine. Arq Neuropsiquiatr. 2011;69(1):39-43. http://dx.doi.org/ 10.1590/s0004-282×2011000100009

23. Darabaneanu S, Overath CH, Rubin D, Luthje S, Sye W, Niederberger $U$ et al. Aerobic exercise as a therapy option for migraine: a pilot study. Int J Sports Med. 2011;32(6):455-560. http://dx.doi.org/ 10.1055/s-0030-1269928

24. Dittrich SM, Gunther V, Franz G, Burtscher M, Holzner B, Kopp $M$. Aerobic exercise with relaxation: influence on pain and psychological well-being in female migraine patients. Clin J Sport Med. 2008;18(4):363-5. http://dx.doi.org/10.1097/JSM.0b013e31817efac9
25. Fernandes-de-las-Peñas C. Physical therapy and exercise in headache. Cephalalgia. 2008;28(1 Suppl):S36-8. http://dx.doi.org/10.1111/ j.1468-2982.2008.01618.x

26. Headache Classification Subcomitte of the Internacional Headache Society. The international classification of headache disorders. Cephalalgia. 2004;24(Suppl s1):36-9. http://dx.doi.org/10.1111/ j.1468-2982.2003.00824.x

27. American College of Sports and Medicine. ACM's Guideline for exercise testing and prescription. 7th ed. Baltimore: Lippincott Willians and Wilkins; 2006.

28. Borg GVA, Noble BJ. Perceived exertion. In: JN Wilmore, editor. Exercise and sport sciences reviews. New York: Academic Press; 1974.

29. Bigal ME, Lipton RB, Holland PR, Goadsby PJ. Obesity, migraine, and chronic migraine: possible mechanisms of interaction. Neurology. 2007;68(21):1851-61. http://dx.doi.org/10.1212/01.wnl.0000262045. 11646.b1 